\title{
Innovation Strategies Impacts on the Performance of Medium-Scale Manufacturing Industries in Central Sulawesi Province, Indonesia
}

\author{
Nursiah $^{1,2^{*}}$, Djayani Nurdin ${ }^{2}$, Suardi ${ }^{2}$, Sulaeman Miru ${ }^{2}$ \\ ${ }^{1}$ Institute of Economic Science of Muhammadiyah Mamuju, Indonesia \\ ${ }^{2}$ Faculty of Economy, Tadulako University, Indonesia
}

DOI: $10.36348 /$ sjef.2020.v04i06.002

| Received: 28.05.2020 | Accepted: 04.06.2020 | Published: 06.06.2020

*Corresponding author: Nursiah

\section{Abstract}

The study aimed to analyze the direct influences of innovation strategies on company performance in Central Sulawesi. This study was conducted in the medium-scale manufacturing industry in Central Sulawesi Province (Palu City and Donggala Regency). The study involved about 96 respondents. The main variables were innovation strategies and company performances. The study found that the average value of the dimension of "process innovation" was 4.11 , high category; while the dimension of "product innovation" had an average value of 4.06, high category. The dimension of product performance had a high value of 3.97 and a marketing performance with a value of 3.92. Hypothesis testing showed that there was a significant influence of innovation strategy on company performance with a P-value $=0.00(\mathrm{P}$ $<0.05$ ) and a regression coefficient value of 0.286 . The conclusion is that the innovation strategy has a positive and significant effect on the performance of the manufacturing industry in Central Sulawesi.

Keywords: Innovation strategy, Industrial performance, manufacturing industry.

Copyright @ 2020: This is an open-access article distributed under the terms of the Creative Commons Attribution license which permits unrestricted use, distribution, and reproduction in any medium for non-commercial use (NonCommercial, or CC-BY-NC) provided the original author and source are credited.

\section{INTRODUCTION}

The economic globalization currently has an impact on changes in the business environment, competition is growing rapidly, and the emergence of new competitors has changed the dynamic of the market, so companies are required to always be proactive in responding to various dynamic changes by creating and developing business strategies. They are facing such rapid changes in multiple aspects that are uncertain, uncontrollable, and unpredictable. To succeed, every company should periodically review the business environment and design some strategies to build upon the changes taking place in the business environment [1].

The increased competitiveness is conducted by producing goods/services at the lowest price, quality products, satisfying sales services, and strengthening marketing channels. These four issues should be considered and resolved by national entrepreneurs if they want to obtain benefits on the competitive advantage of the product they have. Thus the business development target can be achieved through increasing the competitive advantage of entrepreneurs, particularly in the international market. The development of the industrial sector is the main economic development priority without ignoring the development of other areas. The manufacturing industry is one sector that is expected to play a more significant role in the regional and national economy. Small and medium industries would be competing in international trade, which has a complex environment, rapid technological movement, with a fierce level of competition [2]. Competition pattern leads to speed in response to the consumer in the form of provision of goods and services in accordance with the number, type, range, the desired quality, and competitive price.

When an organization starts paying attention to the global competition environment, innovation will be one of the keys to success. Innovation is an alternative for organizations to survive in a dynamic and turbulent environment [3]. The businesses that operate in a very tight competitive environment are required to be innovative if the company is not innovative, then the business will face the risk of having difficulty surviving in an atmosphere of intense competition [4]. The innovation is recognized as a crucial factor in industrial competition and is a formidable weapon for dealing with competition. In addition, innovation is also a key factor in a company's success [5]. This reflects the importance of innovation for organizations in today's business environment. 
Product innovation and development in manufacturing companies, in particular, is an important thing that must be considered in increasing productivity and creating competitive competition in global competition. Manufacturing innovation includes the creation, selection and development/improvement of products, processes, and technology[6]. These innovations may enhance the company's global position and help to achieve status as a world-class quality producer. In innovating, companies need to develop a formal and comprehensive innovation strategy. This strategy reveals the company's goals in innovation, namely by explaining what will be innovated and how to do it.

The purpose of this study was to analyze the direct influences of innovation strategies on company performances in Central Sulawesi.

\section{METHOD}

This research was conducted in registered medium scale manufacturing industries in Central Sulawesi Province (Palu City and Donggala District) with an active status in the Industry and Trade Department, Central Sulawesi. The population in this study was all registered medium scale manufacturing industries (82 industries) with an active status at the Department of Industry and Trade in Central Sulawesi Province. In this study, the sample was the managers of medium-scale manufacturing industries in the Regencies and Cities of Central Sulawesi Province.

\section{Research Variables}

Innovation strategies (X1) is a way to make any changes or new updates in order to achieve organizational goals. Innovations include the creation, selection, development of products, processes, and technologies in the medium-scale industrial enterprises in Central Sulawesi. Innovation strategies measured based on instruments developed by [7], which was consisting of:

a. Process innovation is a form of innovation that emphasizes new methods of operation by creating new technologies or developing existing technologies, consisting of four items, namely: (1) developing new production methods, (2) introducing more production methods, (3) new production methods over the past three years, and (4) production methods compared to industry averages.

b. Product innovation is the result of radically creation and introduction product or modification of existing products so that this type of innovation places more emphasis on the product development, consisting of five items: (1) the level of product innovation, (2) product modification, (3) commitment to significant competitors, (4) commitment to industry averages, (5) introducing products in the last three years.

Company performance ( $\mathrm{Y}$ ) is the level of the company's success in achieving its objectives, the use of various resources in the medium-scale industrial enterprises in Central Sulawesi. Company performances measured based on an instrument developed by [8], which was consisting of:

a. Marketing performance is the success rate of various marketing strategies implementation, to achieve a growth rate of sales, consists of three items: (1) The company's sales growth rate; (2) the average level of sales growth over the past three years; (3) the level of sales growth compared to the growth of the main competitors.

b. Product Performance is the success rate of technology strategy implementation, producing quality products with a better perspective, consists of six items: (1) the durability of the resulting product through a rigorous process; (2) compatibility of design characteristics with technical standards; (3) product images are monitored according to predetermined criteria; (4) product reputation in accordance with specified standards; (5) level of damage or defective product; and (6) conformity of technical criteria for product and service variants.

Analysis of the data that the author used in this study was descriptive analysis and verification analysis, namely the research method aims to test the truth of the hypothesis, which means testing the truth of existing theories.

\section{RESULT AND DISCUSSION}

Table-1: Characteristics of Respondents

\begin{tabular}{|l|c|c|}
\hline Characteristics & n (96 respondents) & \% \\
\hline Sex & 67 & 30 \\
\hline Male & 29 & 70 \\
\hline Female & & \\
\hline Age (Years) & 24 & 25 \\
\hline $20-30$ & 29 & 30 \\
\hline $31-40$ & 43 & 45 \\
\hline$>40$ & & \\
\hline Education & 44 & 46 \\
\hline High school & 2 & 2 \\
\hline Diploma & 46 & 48 \\
\hline Undergraduate & 4 & 4 \\
\hline Graduate & 33 & \\
\hline Work period (Years) & 34 & 36 \\
\hline $1-5$ & 29 & 30 \\
\hline $6-10$ & \multicolumn{2}{|l|}{} \\
\hline$>10$ & & \\
\hline
\end{tabular}


Table 1 shows that the number of respondents in the medium-scale manufacturing industry in Central Sulawesi Province was predominantly male due to workload factors and high responsibility for work. Then the age group > 40 was more dominant, about $45 \%$. This is due to the manufacturing industry requires experience or ability in their field. The higher level of education relatively has an impact on ability or in developing or improving the performance of the manufacturing industry. Then the work period shows that the dominant respondent had a work period was about 6 to 10 years as many as 34 people or $36 \%$. Thus the work period has an impact on the level of knowledge and experience in developing the manufacturing industry.

Table-2: Description of Process Innovation Variables

\begin{tabular}{|c|c|c|c|c|c|c|c|c|c|c|c|}
\hline \multirow[t]{3}{*}{ Process Innovation } & \multicolumn{10}{|c|}{ Statement } & \multirow[t]{3}{*}{ Mean } \\
\hline & \multicolumn{2}{|c|}{$\mathrm{VU}$} & \multicolumn{2}{|c|}{$\mathrm{U}$} & \multicolumn{2}{|c|}{$\mathrm{N}$} & \multicolumn{2}{|c|}{ I } & \multicolumn{2}{|c|}{ VI } & \\
\hline & $\mathrm{n}$ & $\%$ & $\mathrm{n}$ & $\%$ & $\mathrm{n}$ & $\%$ & $\mathrm{~N}$ & $\%$ & $\mathrm{n}$ & $\%$ & \\
\hline Develop new production processes & 2 & 2.1 & 3 & 3.1 & 8 & 8.34 & 48 & 50.0 & 35 & 36.5 & 4.15 \\
\hline Introducing newer production processes & 0 & 0.0 & 1 & 1.0 & 19 & 19.8 & 51 & 53.1 & 25 & 26.0 & 4.04 \\
\hline $\begin{array}{l}\text { Introducing newer production processes } \\
\text { compared to the previous year }\end{array}$ & 2 & 2.1 & 2 & 2.1 & 14 & 14.6 & 51 & 53.1 & 27 & 28.1 & 4.03 \\
\hline $\begin{array}{l}\text { Introducing newer production processes } \\
\text { compared to those carried out by industry }\end{array}$ & 2 & 2.1 & 0 & 0.0 & 8 & 8.3 & 50 & 52.1 & 36 & 37.5 & 4.22 \\
\hline & & & & & & & & & & & 4.11 \\
\hline
\end{tabular}

Note: VU = Very unimportant; U = Unimportant, $\mathrm{N}=$ Neutral, I = Important, VI = Very important

Tables 2 and 3 show that the statement of respondents might be concluded that the mean of "process innovation" dimension with an average value was about 4.11, high category, and "product innovation" dimensions with an average value of 4.06, high category. This indicates that the respondents admitted that introducing or developing new production processes to be the most important competition drivers in the industry, the company benefits from the products being developed. Based on respondents' perceptions (industry owners, production department, and marketing department) about the innovation strategies (process innovation and product innovation) are essential factors for the medium-scale manufacturing industry in Central Sulawesi Province.

Table-3: Description of Product Innovation Variables

\begin{tabular}{|c|c|c|c|c|c|c|c|c|c|c|c|}
\hline \multirow{3}{*}{ Product Innovation } & \multicolumn{10}{|c|}{ Statement } & \multirow{3}{*}{ Mean } \\
\hline & \multicolumn{2}{|c|}{ VU } & \multicolumn{2}{|c|}{$\mathrm{U}$} & \multicolumn{2}{|c|}{$\mathrm{N}$} & \multicolumn{2}{|r|}{ I } & \multicolumn{2}{|c|}{ VI } & \\
\hline & $\mathrm{n}$ & $\%$ & $\mathrm{n}$ & $\%$ & $\mathrm{n}$ & $\%$ & $\mathrm{n}$ & $\%$ & $\mathrm{n}$ & $\%$ & \\
\hline Level of innovation & 2 & 2.1 & 0 & 0.0 & 16 & 16.7 & 48 & 50.0 & 30 & 31.2 & 4.08 \\
\hline $\begin{array}{l}\text { The level of effort in modifying / renewing } \\
\text { the product }\end{array}$ & 2 & 2.1 & 0 & 0.0 & 20 & 20.8 & 46 & 47.9 & 28 & 29.2 & 4.02 \\
\hline Introducing more new products & 1 & 1.0 & 2 & 2.1 & 15 & 15.6 & 53 & 55.2 & 25 & 26.0 & 4.02 \\
\hline $\begin{array}{l}\text { Introducing more new products than the } \\
\text { industry average }\end{array}$ & 2 & 2.1 & 1 & 1.0 & 9 & 9.4 & 47 & 49.0 & 37 & 38.5 & 4.20 \\
\hline $\begin{array}{l}\text { Introducing more new products than the } \\
\text { previous year }\end{array}$ & 2 & 2.1 & 1 & 1.0 & 20 & 20.8 & 46 & 47.9 & 27 & 28.1 & 3.98 \\
\hline & & & & & & & & & & & 4.06 \\
\hline
\end{tabular}

Note: VU = Very unimportant; U = Unimportant, $\mathrm{N}=$ Neutral, I = Important, VI = Very important

Table-4: Description of Marketing Performance Variables

\begin{tabular}{|c|c|c|c|c|c|c|c|c|c|c|c|}
\hline \multirow{3}{*}{ Marketing Performance } & \multicolumn{10}{|c|}{ Statement } & \multirow{3}{*}{ Mean } \\
\hline & \multicolumn{2}{|c|}{ VU } & \multicolumn{2}{|c|}{$\mathrm{U}$} & \multicolumn{2}{|c|}{$\mathrm{N}$} & \multicolumn{2}{|c|}{ I } & \multicolumn{2}{|c|}{ VI } & \\
\hline & $\mathrm{n}$ & $\%$ & $\mathrm{~N}$ & $\%$ & $\mathrm{n}$ & $\%$ & $\mathrm{n}$ & $\%$ & $\mathrm{n}$ & $\%$ & \\
\hline The company's average sales growth & 0 & 0.0 & 6 & 6.02 & 21 & 21.9 & 28 & 29.2 & 41 & 42.7 & 4.08 \\
\hline $\begin{array}{l}\text { The company's average sales growth } \\
\text { compared to its main competitors }\end{array}$ & 3 & 3.1 & 0 & 0.0 & 35 & 36.5 & 31 & 32.2 & 27 & 28.1 & 3.82 \\
\hline $\begin{array}{l}\text { The company's average sales growth } \\
\text { compared to the previous year }\end{array}$ & 3 & 3.1 & 4 & 4.2 & 25 & 26.0 & 34 & 35.4 & 30 & 31.2 & 3.97 \\
\hline \multicolumn{11}{|c|}{ Mean } & 3.92 \\
\hline
\end{tabular}

Note: VU = Very unimportant; U = Unimportant, $\mathrm{N}=$ Neutral, I = Important, VI = Very important 
Table-5: Description of Product Performance Variable

\begin{tabular}{|c|c|c|c|c|c|c|c|c|c|c|c|}
\hline \multirow{3}{*}{ Product Performance } & \multicolumn{10}{|c|}{ Statement } & \multirow{3}{*}{ Mean } \\
\hline & \multicolumn{2}{|c|}{$\mathrm{VU}$} & \multicolumn{2}{|c|}{$\mathrm{U}$} & \multicolumn{2}{|c|}{$\mathrm{N}$} & \multicolumn{2}{|r|}{ I } & \multicolumn{2}{|c|}{ VI } & \\
\hline & $\mathrm{n}$ & $\%$ & $\mathrm{n}$ & $\%$ & $\mathrm{n}$ & $\%$ & $\mathrm{n}$ & $\%$ & $\mathrm{n}$ & $\%$ & \\
\hline Introducing new products & 0 & 0.0 & 1 & 1.0 & 39 & 40.6 & 24 & 25.0 & 32 & 33.1 & 3.90 \\
\hline Offering new product models or new technologies & 0 & 0.0 & 0 & 0.0 & 35 & 36.5 & 29 & 30.2 & 32 & 33.1 & 3.97 \\
\hline Maintaining strength in the development field & 1 & 1.0 & 0 & 0.0 & 17 & 17.7 & 48 & 50.0 & 30 & 31.2 & 4.10 \\
\hline Pioneering product change & 1 & 1.0 & 0 & 0.0 & 37 & 38.5 & 35 & 36.5 & 23 & 24.0 & 3.82 \\
\hline Introducing new products ahead of competitors & 0 & 0.0 & 0 & 0.0 & 26 & 27.1 & 43 & 46.9 & 25 & 26.0 & 3.99 \\
\hline $\begin{array}{l}\text { Coping strategies of the most famous industry in } \\
\text { introducing new products and new technologies }\end{array}$ & 0 & 0.0 & 0 & 0.0 & 22 & 22.9 & 47 & 49.0 & 27 & 28.1 & 4.05 \\
\hline \multicolumn{11}{|c|}{ Mean } & 3.97 \\
\hline
\end{tabular}

Note: VU = Very unimportant; U = Unimportant, $\mathrm{N}=$ Neutral, I = Important, VI = Very important

Tables 4 and 5 show that the dimensions of product performance had high value (mean) of 3.97. This indicates that performance is crucial to be considered if the company wants a high performance, then followed by marketing performance with a value (mean) of 3.92.

Table-6: The Test of Hypothesis
\begin{tabular}{|l|c|l|c|c|c|c|c|}
\hline & Estimate & S.E. & C.R. & P & Note \\
\hline Innovation strategy & $\rightarrow$ & Company performance & 0.286 & 0.051 & 5.556 & 0.000 & Sig. \\
\hline
\end{tabular}

For the variable of innovation strategy, the calculation shows that the regression coefficient was 0.286 , while the P-value was 0.000 . Thus the value of $\alpha$ $<0.05$ at $95 \%$ confidence level. So it can be stated that the innovation strategy variable has a significant influence on company performance in the medium-scale manufacturing industry in Central Sulawesi Province.

Based on the results of this study indicate that the variable of innovation strategy has a positive effect on company performance in the medium-scale manufacturing industry in the Province of Central Sulawesi. This is evidenced by looking at the P-value comparison with the $\alpha$ value obtained and reinforced by the empirical findings from the respondents' statements.

The innovation strategy has a significant effect on company performance [9]. Researchers have used the simultaneous model in several studies to link the innovation strategy of a company with its financial performance[6]. They realize that the strengths of the simultaneous model will provide a clear picture of the direct correlation between the variables of the innovation strategy and the company's financial performance.

Innovation is the most important issue in business because it is able to change the market situation by reducing the ability of large market participants and encouraging outside behavior to occupy high positions [10]. Without innovation, market players can lose their position, and it will be difficult to rebuild their performance in the industry. Innovation is very important to be able to compete well with other competitors [11]. To produce a product that can be accepted by the public well, it is necessary to have a mature innovation strategy concept to achieve a competitive advantage. Products that are made in order to have a competitive advantage do not have to be unique, because a unique product may not necessarily be accepted by the market because it is not in line with consumer expectations.

In the current condition of the knowledge economy, a process of creating sustainable value is more generated from intangible assets such as the skills and knowledge of employees with the support of information technology and organizational climate that strongly supports innovation. BSC (Balanced Scorecard Companies) can be a blueprint to provide a framework that links between intangible assets with tangible assets in the process of creation of value for the consumer (Tangible resources include: staff skills, customer quality, production cost efficiency and product quality; very intangible resources include: morale of staff, reputation in the eyes of customers, and reputation in the eyes of investors). A strategy map is a logical architecture in translating strategy because this tool is the basis of how to design a Business Scorecard as a foundation of a "Strategic Management System" that will be able to overcome various obstacles that arise in the measurement of industrial-era performance which is usually more focused on measurement systems only on the tangible assets.

The company consists of a group of business units, departments, or sections, each of which usually has its strategy. Synergy is the keyword of the goal to be achieved through organizational design. To achieve the desired performances, then each strategy was integrated. Functional barriers that exist in a company that often become obstacles in the implementation of the strategy, therefore, Kaplan \& Norton [12] states that through "the strategic architecture" which is nothing but linking and uniting the scorecards of each unit by applying the theory they called "The theory managing 
share service units," and the decentralization step of business units within a corporate entity [12].

How to create a strategy on the agenda of each person in a company. The question that often arises is how a strategy designed at the level of the strategic business unit can be implemented to the lowest level of a company (frontlines). To implement a strategy focused on, all employees without exception understand the strategy and apply in daily activities to contribute to the success of strategy has been outlined at the corporate level. This is not a top-down direction, but a top-down Communication. At this level, company executives must be able to develop innovative forms of communication, because this is a basic foundation in creating awareness of strategies at all levels in the company. Each manager is able to clearly describe the measurements used as a guide in monitoring the strategy so that each employee understands what is expected of them so that it will help him in making decisions and actions towards the intended strategy.

Innovation is part of a framework that connects aspects of corporate culture with the ability to innovate and improve company performance through consumer buying decisions [13]. The results showed that the higher the product innovation carried out by the company would improve the company's performance through increased buying decisions [14]. In global competition, companies must be able to modify their products to add value to the products they produce and must be able to meet the needs and tastes that fit the consumer.

\section{CONCLUSION}

The innovation strategy has a significant effect on the performance of medium-scale manufacturing industry companies in Central Sulawesi Province.

\section{REFERENCES}

1. Reeves, M., Love, C., \& Tillmanns, P. (2012, September 1). Your Strategy Needs a Strategy. Harvard Business Review, September 2012. https://hbr.org/2012/09/your-strategy-needs-astrategy

2. Litsareva, E. (2017). Success Factors of AsiaPacific Fast-Developing Regions' Technological Innovation Development and Economic Growth. International Journal of Innovation Studies, 1(1), $72-88$.
3. Hisrich, R. D., \& Kearney, C. (2013). Managing Innovation and Entrepreneurship. SAGE Publications.

4. Rajapathirana, R. P. J., \& Hui, Y. (2018). Relationship between innovation capability, innovation type, and firm performance. Journal of Innovation \& Knowledge, 3(1), 44-55.

5. Frambach, R. T., \& Schillewaert, N. (2002). Organizational innovation adoption: A multi-level framework of determinants and opportunities for future research. Journal of Business Research, 55(2), 163-176.

6. Zahra, S. A., \& Das, S. R. (2009). Innovation strategy and financial performance in manufacturing companies: An empirical study. Production and Operations Management, 2(1), 1537.

7. Read, A. (2000). Determinants of successful organisational innovation: A review of current research. Journal of Management Practice, 3(1), 95-119.

8. Zhou, H., Uhlaner, L., \& Tan, S. (2007). Knowledge management and innovation: An empirical study of Dutch SMEs. Journal of Economic Education - J ECON EDUC, 1-44.

9. Ezzi, F., \& Jarboui, A. (2016). Does innovation strategy affect financial, social and environmental performance? Journal of Economics, Finance and Administrative Science, 21(40), 14-24.

10. Hauser, J., Tellis, G. J., \& Griffin, A. (2006). Research on Innovation: A Review and Agenda for Marketing Science. Marketing Science, 25(6), 687717.

11. Distanont, A., \& Khongmalai, O. (2018). The role of innovation in creating a competitive advantage. Kasetsart Journal of Social Sciences.

12. Kaplan, R. S., \& Norton, D. P. (1992, January 1). The Balanced Scorecard-Measures that Drive Performance. Harvard Business Review, JanuaryFebruary 1992. https://hbr.org/1992/01/thebalanced-scorecard-measures-that-driveperformance-2

13. Padilha, C. K., \& Gomes, G. (2016). Innovation culture and performance in innovation of products and processes: A study in companies of textile industry. RAI Revista de Administração $e$ Inovação, 13(4), 285-294.

14. Hasnatika, I. F., \& Nurnida, I. (2018). Analisis Pengaruh Inovasi Produk Terhadap Keunggulan Bersaing Pada UKM "Duren Kamu Pasti Kembali" di Kota Serang. Jurnal Riset Bisnis Dan Investasi, 4(3), 1-9. 